\title{
Cyber Literature Apps Effectiveness in Learning Literature
}

\author{
Basri $^{1}$, Andi Febriana Tamrin ${ }^{2}$ \\ \{basri@unifa.ac.id ${ }^{1}$, andifebriana90@gmail.com ${ }^{2}$ \} \\ Universitas Fajar, Sulawesi Selatan, Indonesia ${ }^{12}$
}

\begin{abstract}
Undeniable, technology advancement has spread to all fields, with no exception in literature advancement. This phenomenon has resulted various changing in literary field in concrete terms in literary genre. In literature, Indonesia also has applied information and technology in the terms of teaching and advancement. This study is aimed determining the cyber literature application effectiveness in literature learning. This study applied Mix Method. Research respondents were second-year students of the English Literature Study Program taking the Basic Literature course. This study used cognitive theory to determine the students' cognitive development. Based on the pre and post test result, the use of the cyber literature application was quite effective in increasing students' cognitive knowledge in literature. The test results showed that 9 respondents or as much as $40.9 \%$ experienced an increased level of cognitive knowledge; 5 respondents or as much as $22.7 \%$ experienced a constant level of knowledge; and 8 respondents or as much as $36.3 \%$ experienced a decreased level of cognitive knowledge.
\end{abstract}

Keywords: cognitive development, cyber literature apps, literature.

\section{Efektivitas Aplikasi Sastra Siber dalam Pembelajaran Sastra}

\begin{abstract}
Abstrak. Tidak dipungkiri kemajuan teknologi telah menyebar ke segala bidang, tidak terkecuali dalam kemajuan ilmu sastra. Fenomena ini menghasilkan perubahan yang beragam dalam bidang ilmu sastra secara konkrit pada genre sastra Dalam bidang ilmu sastra, Indonesia turut menerapkan teknologi dan informasi untuk pengajaran dan kemajuannya. Penelitian ini bertujuan mengetahui keefektifan aplikasi sastra siber pada pembelajaran ilmu sastra. Penelitian ini menggunakan metode penelitian campuran. Responden penelitian adalah mahasiswa tingkat dua Program Studi Sastra Inggris yang mengambil mata kuliah Dasar-Dasar Ilmu Sastra. Penelitian ini menggunakan teori kognitif untuk mengetahui perkembangan kognitif mahasiswa. Berdasarkan hasil pra-uji dan pasca-uji, penggunaan aplikasi sastra siber cukup efektif dalam meningkatkan pengetahuan kognitif mahasiswa dalam ilmu sastra. Hasil pengujian menunjukkan bahwa 9 responden atau sebanyak 40,9\% mengalami tingkat pengetahuan kognitif yang meningkat; 5 responden atau sebanyak $22,7 \%$ mengalami tingkat pengetahuan kognitif tetap; dan 8 responden atau sebanyak 36,3\% mengalami tingkat pengetahuan kognitif menurun.
\end{abstract}

Kata kunci: perkembangan kognitif, aplikasi sastra siber, ilmu sastra. 


\section{Pendahuluan}

Di zaman digitalisasi saat ini, teknologi dan multimedia menjadi sebuah nafas baru dalam bidang pendidikan. Dengan kemajuan teknologi yang begitu pesat, seluruh tingkat masyarakat, anak-anak maupun dewasa dituntut untuk mengikuti kemajuan tersebut. Kemajuan teknologi juga telah menyebar ke seluruh bidang, tidak terkecuali karya sastra.

Di zaman sebelum komputer menyeruak di awal abad 21, karya sastra dapat dinikmati secara luring dengan jumlah cetak yang terbatas serta dengan beragam harga. Pun tidak semua tempat penjualan kaya sastra menyajikan versi atau jenis yang diinginkan sebagian pembaca. Dalam hal pembelajaran ilmu sastra, metode yang dulu diterapkan masih terbilang "tradisional" yang menyebabkan siswa/mahasiswa menikmati sebuah bacaan hanya melalui media cetak yang jumlah dan tempatnya terbatas, seperti perpustakaan.

Dewasa ini, hal tersebut berbanding terbalik. Saat ini, pembaca dapat menikmati suatu karya sastra secara daring. Mereka mudah untuk mendapatkan sesuatu yang ingin dibaca dikarenakan begitu banyaknya situs daring yang menyediakan bacaan atau dapat diunduh secara berlangganan maupun gratis. Selain hal tersebut, internet juga menyediakan ruang bagi pemula dalam menyalurkan kemampuan dan pemikiran pembaca dalam bentuk tulisan. Beragam situs seperti Webnovel, Wattpad, Inkitt dan lainnya menyediakan ruang tersebut dan sekarang telah berkembang menjadi sebuah aplikasi yang dapat diperoleh di smartphone ataupun tablet. Perkembangan ini membuka sebuah peluang bagi para penulis pemula untuk menyalurkan kemampuan dan eksistensi mereka di tengah jejaring komunikasi global tanpa sebuah batasan. Hal ini juga memaksimalkan hubungan antara junior dan senior dalam dunia sastra. Perkembangan kedua hal ini menjadi pertanda sebuah hal positif pada kalangan muda.

Sumardjo \& Saini (1997) menyatakan sastra sebagai suatu ekspresi yang muncul pada pribadi yang berkaitan dengan perasaan, pengalaman, ide dan pikiran, keyakinan dan kepercayaan serta semangat. Ekspresi tersebut tergambar dengan dibangkitkannya suatu rasa yang menjadi daya pikat dengan bahasa sebagai alat (medium) [1]. Hal ini tentunya memunculkan unsur-unsur menarik sastra berupa pemikiran, pengalaman, gagasan, kepercayaan (keyakinan), ekspresi atau ungkapan serta bentuk dan bahasa. Pendapat ini dikuatkan oleh Saryono (2009) dalam Sumardjo \& Saini yang mengemukakan bahwa sastra memiliki kapabilitas untuk merekam seluruh jejak pengalaman secara empiris-natural maupun pengalaman secara nonempiris-supernatural sehingga sastra dipercaya mampu untuk menjadi spectator kehidupan manusia [1].

Definisi tersebut terhubung dengan kemajuan aplikasi sastra siber di Indonesia. Ini menjadi sebuah fenomena yang butuh animo khusus dikarenakan mampu memberikan kontribusi pada kemajuan sastra di Indonesia. Tidak hanya itu, kemajuan ini juga menjadi animo pada bidang pendidikan seiring perkembangan budaya internet yang menyebabkan perkembangan sastra siber tersebut.

Neuage pada Influence of the World Wide Web on Literature (1997), menyatakan tentang kelahiran sebuah sastra siber sekitar 1990. Akan tetapi, pada sekitar tahun 1998 sastra siber baru berada pada puncak popularitas. Kepopulerannya diiringi dengan munculnya komunitaskomunitas sastra siber yang semakin berkembang. Komunitas ini lebih banyak memanfaatkan layanan aplikasi yang ditawarkan oleh internet seperti situs mailing, forum serta blog. Tidak hanya hal tersebut, penggunaan jejaring sosial atau media sosial merupakan sebuah faktor utama penyebab berkembangnya kreativitas dari komunitas ini. Jejaring sosial yang umumnya memfasilitasi mereka adalah Twitlonger (perkembangan dari Twitter), Wattpad, FanFiction, serta fitur catatan pada laman Facebook, dan laman lainnya [2]. 
Namun demikian, penggunaan aplikasi sastra siber masih langka diterapkan sebagai media pembelajaran ilmu sastra di kalangan akademis. Sebagai hasilnya, fenomena tersebut menjadi daya tarik penting sehingga patut untuk diteliti. Tidak hanya itu, perkembangan dan keberadaan aplikasi serta genre sastra siber bisa dijangkau di seluruh pelosok Negara, tidak hanya di Indonesia. Penelitian ini merupakan sebuah urgensi yang penting dikarenakan masyarakat saat ini merupakan sebuah cerminan yang tertulis pada karya sastra. Masyarakat cenderung menuju ke arah yang lebih maju (modern), ikut berpartisipasi dalam perkembangan sastra siber. Oleh karena itu, penelitian ini memiliki tujuan untuk mengupas tingkat keefektifan penerapan aplikasi dan genre siber sastra selama proses pembelajaran mahasiswa pada ilmu sastra.

Berdasarkan penelitian terdahulu, dalam dunia maya, khususnya yang menyediakan karya sastra berbentuk digital (cyber), karya sastra tersebut dikonsumsi bersamaan dengan isi dari konten yang disediakan oleh pemilik domain atau situs tersebut. Hal tersebut dapat dibuktikan berdasarkan hasil penelitian yang telah dilaksanakan oleh Nanda \& Susanto dalam karyanya yang berjudul The Emergence of Cyber Literature: A Challenge to Teach Literature from Text to Hypertext. Menurut mereka, di zaman digital ini, dunia maya telah menjadi bagian dari masyarakat. Perkembangan teknologi yang begitu pesat memaksa masyarakat untuk beradaptasi terhadap hal tersebut [3].

Penelitian ini dipusatkan di Universitas Fajar dengan sampel mahasiswa semester 3 Program Studi Sastra Inggris. Skema penelitian ini adalah penelitian dosen pemula dengan harapan mampu menjadi bahan referensi dan dasar bagi penelitian selanjutnya.

\section{Metode}

Metode yang diterapkan pada penelitian ini merupakan metode kombinasi (Mix Method), yaitu sebuah metode penggabungan antara kualitatif dan kuantitatif. Pengumpulan, penganalisaan, serta penggabungan data secara kualitatif dan kuantitatif menjadi fokus dari penelitian ini. Metode ini dianggap mampu untuk menghasilkan sebuah jawaban serta pemahaman dari fenomena yang terjadi sehingga metode ini dipandang lebih baik dibandingkan metode lainnya untuk mengemukakan jawaban dari masalah penelitian.

Metode kombinasi ini terbagi menjadi 4 bagian, yaitu embedded, explanatory, exploratory, dan triangulation. Pada tahap permulaan, peneliti menerapkan metode kualitatif kemudian kuantitatif yang menekankan lebih banyak pada metode kualitatif dan selanjutnya dilengkapi oleh metode kuantitatif. Penggabungan kombinasi data dari kedua metode bersifat connecting (menghubungkan) antara hasil pertama dan berikutnya [4].

\section{Hasil dan Pembahasan}

Menurut teori kognitif, secara prinsip, belajar merupakan sebuah perkembangan atau perubahan persepsi berdasarkan perubahan tingkah laku yang konkret serta perubahan pada akal pikiran manusia. Winkel menyatakan bahwa belajar merupakan sebuah aktivitas menggunakan mental dan psikis yang sebenarnya sedang atau telah terjadi saat adanya interaksi aktif dengan lingkungan belajar dimana nantinya akan dapat menghasilkan suatu bentuk perubahan pengetahuan, pemahaman, keterampilan, kemampuan, nilai dan sikap. Hal ini menjadi suatu hal yang relatif dan berbekas [5]. 
Menurut pernyataan Gradler dalam Anidar (2011: 324) fokus dari teori kognitif Jean Piaget adalah untuk mendapatkan asal mula dari logika alamiah dan bentuk perubahannya dalam hal penalaran ke penalaran lainnya. Dengan demikian, hal ini bertujuan untuk mengharuskan dilakukannya penelitian terhadap akar dari suatu pemikiran yang logis pada bayi, pun dengan jenis penalaran yang ada pada anak kecil, dan terakhir proses penalaran yang ada pada remaja dan dewasa [6]. Mengacu pada hal tersebut, Piaget telah menyatakan proses belajar hanya akan terjadi bila adanya suatu kegiatan yang dilakukan secara individual seperti interaksi terhadap lingkungan sosial dan fisik. Selanjutnya, perkembangan dan pertumbuhan yang dialami oleh suatu individu dinyatakan sebagai sebuah proses sosial. Interaksi yang dilakukan oleh individu dengan lingkungan fisiknya, tidak berarti interaksi ini dilakukan sebagai sebuah individu yang terikat, melainkan bagian dari sebuah grup sosial. Interaksi individu dengan individu lain memegang peranan besar dalam perkembangan pandangan individu terhadap alam. Melalui pertukaran gagasan dengan individu lainnya, individu yang sebelumnya memiliki pandangan subjektif terhadap sesuatu yang telah diamatinya akan mengalami perubahan ke arah objektif.

Pada penelitian ini, peneliti menggunakan salah satu sastra siber yang dapat diakses melalui situs secara daring maupun mengunduh aplikasinya pada perangkat elektronik. Wattpad, salah satu media sastra siber atau sastra daring, mengizinkan penggunanya untuk menulis ataupun membaca sebuah karya sastra. Wattpad memiliki keunggulan seperti banyaknya karya sastra yang popular serta modern dan menghasilkan penulis-penulis ternama yang pada awalnya hanya menyalurkan hobi mereka serta penggunaannya yang praktis. Selain keunggulan tersebut, Wattpad juga dapat diakses secara luring apabila pengguna telah mengunduh karya yang ingin dibaca.

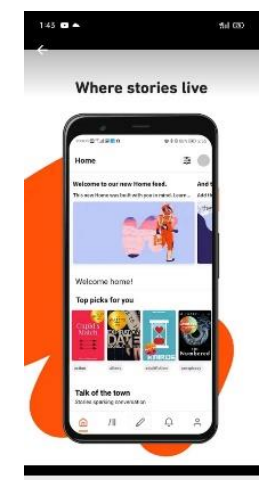

Gambar 1. Wattpad Mobile

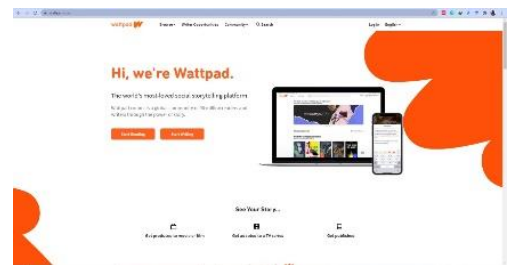

Gambar 2. Wattpad Situs

Sebelum memulai penelitian, peneliti menyusun kuesioner pra-uji yang bertujuan untuk mengumpulkan data dengan indikator jangkauan pengetahuan sampel terkait ilmu sastra secara awam. Kuesioner tersebut berisikan 13 poin pertanyaan yang telah disusun dengan indikator sebagai berikut: 1) bertujuan mengetahui tingkat pengetahuan sampel terkait ilmu sastra secara awam; 2) untuk mengetahui pendapat sampel terkait ilmu sastra; dan 3) tingkat ketertarikan sampel terhadap ilmu sastra.

Dengan perumusan:

$($ Mean Responden $)=\underline{\text { Jumlah Respons di Atas Skala } 3(a+b+c+d+\ldots .)}$ Jumlah Responden 
(Mean Responden) $=\mathbf{1 6 0 / 2 2}$

(Mean Responden) $=7,1$

Tabel 1. Hasil Pre-Test

\begin{tabular}{cc}
\hline Jumlah Responden & Mean Responden \\
\hline 22 & 7,1 \\
\hline
\end{tabular}

Setelah itu, disaat menjelang waktu akhir semester, peneliti kemudian melanjutkan pengumpulan data melalui kuesioner pasca-uji untuk mengetahui tingkat perubahan pengetahuan kognitif yang dialami oleh mahasiswa terkait ilmu sastra. Selama proses pembelarajannya, peneliti menerapkan aplikasi sastra siber sebagai media pengajaran ilmu sastra. Berikut merupakan hasil dari kuesioner pasca-uji:

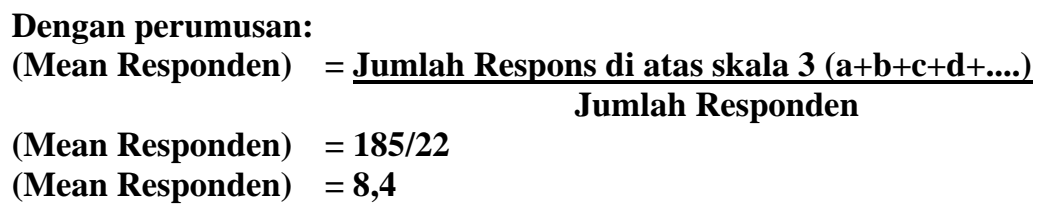

Tabel 2. Hasil Post-Test

\begin{tabular}{cc}
\hline Jumlah Responden & Mean Responden \\
\hline 22 & 8,4 \\
\hline
\end{tabular}

Kemudian diperoleh hasil sebagai berikut:

Tabel 3. Kuesioner Hasil Perubahan

\begin{tabular}{ccccc}
\hline No & Responden & Pra-uji & Pasca-uji & $\begin{array}{c}\text { Hasil } \\
\text { Perubahan }\end{array}$ \\
\hline 1. & $\mathrm{~A}$ & 5 & 10 & $\mathrm{~N}$ \\
2 & $\mathrm{~B}$ & 4 & 8 & $\mathrm{~N}$ \\
3 & $\mathrm{C}$ & 3 & 7 & $\mathrm{~N}$ \\
4 & $\mathrm{D}$ & 2 & 7 & $\mathrm{~N}$ \\
5 & $\mathrm{E}$ & 5 & 13 & $\mathrm{~N}$ \\
6 & $\mathrm{~F}$ & 5 & 8 & $\mathrm{~N}$ \\
7 & $\mathrm{G}$ & 5 & 5 & $\mathrm{~K}$ \\
8 & $\mathrm{H}$ & 9 & 8 & $\mathrm{~T}$ \\
9 & $\mathrm{I}$ & 11 & 10 & $\mathrm{~T}$ \\
10 & $\mathrm{~J}$ & 8 & 5 & $\mathrm{~T}$ \\
11 & $\mathrm{~K}$ & 10 & 7 & $\mathrm{~T}$ \\
12 & $\mathrm{~L}$ & 9 & 9 & $\mathrm{~K}$ \\
13 & $\mathrm{M}$ & 8 & 8 & $\mathrm{~K}$ \\
14 & $\mathrm{~N}$ & 11 & 6 & $\mathrm{~T}$ \\
15 & $\mathrm{O}$ & 13 & 12 & $\mathrm{~T}$ \\
16 & $\mathrm{P}$ & 9 & 9 & $\mathrm{~K}$ \\
17 & $\mathrm{Q}$ & 9 & 7 & $\mathrm{~T}$ \\
18 & $\mathrm{R}$ & 11 & 9 & $\mathrm{~T}$ \\
19 & $\mathrm{~S}$ & 6 & 10 & $\mathrm{~N}$
\end{tabular}




\begin{tabular}{ccccc}
20 & $\mathrm{~T}$ & 8 & 8 & $\mathrm{~K}$ \\
21 & $\mathrm{U}$ & 5 & 12 & $\mathrm{~N}$ \\
22 & $\mathrm{~V}$ & 4 & 7 & $\mathrm{~N}$ \\
Jumlah Mean (Keseluruhan) & 160 & 185 & \\
\hline Keterangan: & N= NAIK (Meningkat) & & \\
$\mathrm{T}=$ TURUN (Menurun) & & & \\
K= KONSTAN (Tetap) &
\end{tabular}

Berdasarkan tabel 1, hasil pra-uji menunjukkan hasil dari pengetahuan kognitif dari sampel terkait ilmu sastra yaitu sebanyak 7.1 atau sebesar $54.6 \%$ telah mengetahui seputar ilmu sastra secara umum serta tabel 2 hasil pasca-uji menunjukkan bahwa sampel memiliki pengetahuan (kognitif) tentang ilmu sastra dengan rata-rata nilai/jumlah 8.4 atau sebesar 64.6\%. Kedua hal tersebut diperoleh dari sebanyak 22 sampel (responden).

Selanjutnya diperoleh hasil atau simpulan bahwa responden mengalami tingkat pengetahuan cukup beragam yang dapat dilihat pada tabel 3, dan hasil pengamatannya dapat dilihat di bawah ini:

1) Sembilan responden mengalami perubahan tingkat pengetahuan kognitif NAIK yang dipicu oleh minat mereka terhadap teknologi atau aplikasi sastra siber, serta selama proses pembelajarannya, perhatian responden berfokus pada apa yang diterangkan dan berperan aktif dalam diskusi.

2) Lima responden tidak mengalami perubahan tingkat pengetahuan kognitif atau KONSTAN, yang disebabkan oleh kurang fokusnya pada materi pembelajaran yang dilakukan oleh peneliti dan berperan kurang aktif dalam diskusi serta minat baca yang rendah.

3) Delapan responden mengalami perubahan tingkat pengetahuan kognitif TURUN disimpulkan dari pasifnya responden saat proses pembelajaran, kurang tertarik dengan materi ajar berbasis siber serta kurangnya minat membaca.

Berdasarkan dari hasil yang telah didapatkan selama proses penelitian, penerapan sastra siber cukup efektif dalam peningkatan pengetahuan kognitif mahasiswa mengenai ilmu sastra. Hal ini ditunjukkan oleh hasil perbandingan yang diperoleh dari pra-uji dan pasca-ujit. Sastra siber dapat dikategorikan sebagai media yang cukup membantu dalam pengembangan pengetahuan mahasiswa.

Sesuai yang dikemukakan oleh Piaget, 9 responden yang mengalami tingkat pengetahuan kognitif NAIK melakukan sebuah interaksi dengan linkungan fisik serta sosialnya. Lingkungan fisik yang dimaksud merupakan media sastra siber yang digunakan dalam proses pembelajarannya. Dan sosialnya adalah lingkungan kelas serta keaktifan dalam melontarkan pertanyaan-pertanyaan seputar siber sastra maupun karya sastra yang terdapat dalam media yang digunakan.

Interaksi yang dilakukan hanya dengan lingkungan sosial saja belum tentu meningkatkan tingkat pengetahuan responden. Hal ini dialami oleh 5 responden yang mengalami tingkat pengetahuan kognitif KONSTAN. Selama proses pembelajarannya, responden tidak memiliki ketertarikan pada lingkungan fisik atau media siber sastra yang digunakan. Interaksi dengan lingkungan sosial memanglah terjadi selama proses pembelajarannya, tetapi sosial yang dimaksudkan di sini adalah interaksi antara 5 responden itu maupun ke responden lainnya. Ketika interaksi sosial tersebut terjadi, responden NAIK yang ditanya atau yang diajak berinteraksi mengenai pembelajaran yang dilakukan ini belumlah tentu memahami dikarenakan responden tersebut juga sedang dalam proses pembelajaran. Hal ini hanya 
memicu rasa keingintahuan dari responden NAIK yang ditanya oleh responden KONSTAN sehingga melakukan interaksi dengan lingkungan fisiknya maupun interaksi sosial kepada pengajar.

Sementara itu, 8 responden yang mengalami penurunan sama sekali tidak melakukan interaksi fisik maupun sosial mengenai pembelajaran yang dilakukan ini. Mereka hanya berinteraksi mengenai hal-hal lain, serta berperan pasif dalam kelas selama proses pembelajaran. Kurangnya interaksi dengan lingkungan fisik yang diakibatkan tidak adanya ketertarikan membaca ataupun dipicu oleh hal-hal lainnya sehingga tingkat pengetahuan kognitif mereka pun TURUN.

\section{Simpulan}

Berdasarkan hasil pra-uji dan pasca-uji, penggunaan aplikasi sastra siber cukup efektif dalam meningkatkan pengetahuan kognitif mahasiswa dalam ilmu sastra. Hasil pengujian menunjukkan bahwa 9 responden atau sebanyak 50,9\% mengalami tingkat pengetahuan kognitif yang meningkat; 5 responden atau sebanyak $22,7 \%$ mengalami tingkat pengetahuan kognitif tetap; dan 8 responden atau sebanyak 36,4\% mengalami tingkat pengetahuan kognitif menurun.

\section{Referensi}

[1] Zulfahnur. Lingkup ilmu sastra: Teori sastra, sejarah sastra, dan kritik sastra, serta hubungan antara ketiganya. Universitas Terbuka. 2014; 1 (37).

[2] Supriatin YM. Kritik sastra cyber. Jurnal Sosioteknologi. 2012; 11 (25): 47-54.

[3] Nanda DS, Susanto S. The emergence of cyber literature: A challenge to teach literature from text to hypertext 2020. doi:10.35542/osf.io/q8psj.

[4] Sugiyono PD. Metodologi penelitian. Journal of Chemical Information and Modeling. 2016; 53 (9): 1689-1699.

[5] Sutarto S. Teori kognitif dan implikasinya dalam pembelajaran. Islamic Counseling: Jurnal Bimbingan dan Konseling Islam. 2017; 1 (2): 1-26.

[6] Ekawati M. Teori belajar menurut aliran psikologi kognitif serta implikasinya dalam proses belajar dan pembelajaran. E-Tech: Jurnal Ilmiah Teknologi Pendidikan. 2019; 7 (2): 1-12 